\title{
Metal-tolerant fungal communities are delineated by high zinc, lead, and copper concentrations in metalliferous Gobi Desert Soils
}

Article

Accepted Version

Kerfah, D., Ogwu, M. C., Dagvatseren, D., Balt, A., Davaasuren, D., Enkhmandal, O., Purevsuren, T., Batbaatar, A., Tibbett, M., Undrakhbold, S., Boldgiv, B. and Adams, J. M. (2020) Metal-tolerant fungal communities are delineated by high zinc, lead, and copper concentrations in metalliferous Gobi Desert Soils. Microbial Ecology, 79. pp. 420-431. ISSN 1432-184X doi: https://doi.org/10.1007/s00248-019-01405-8 Available at https://centaur.reading.ac.uk/84864/

It is advisable to refer to the publisher's version if you intend to cite from the work. See Guidance on citing.

To link to this article DOI: http://dx.doi.org/10.1007/s00248-019-01405-8

Publisher: Springer

All outputs in CentAUR are protected by Intellectual Property Rights law, including copyright law. Copyright and IPR is retained by the creators or other copyright holders. Terms and conditions for use of this material are defined in the End User Agreement. 


\section{www.reading.ac.uk/centaur}

\section{CentAUR}

Central Archive at the University of Reading

Reading's research outputs online 


\section{Metal tolerant fungal communities are delineated by high zinc, lead and copper}

\section{2 concentrations in metalliferous Gobi desert soils}

3 Dorsaf Kerfahi ${ }^{1}$, Matthew Chidozie Ogwu ${ }^{2}$, Dagvatseren Ariunzaya $^{3}$, Altantsetseg Balt ${ }^{4}$,

4 Dulamsuren Davaasuren ${ }^{4}$, Orsoo Enkhmandal ${ }^{3}$, Tsolmonjav Purevsuren ${ }^{4}$, Amgaa Batbaatar ${ }^{4,5}$,

5 Mark Tibbett $^{6}$, Sainbileg Undrakhbold ${ }^{3}$, Bazartseren Boldgiv ${ }^{3 *}$, Jonathan M. Adams ${ }^{7 *}$

$6 \quad{ }^{1}$ School of Applied Biosciences, College of Agriculture and Life Sciences, Kyungpook National

7 University, Daegu, 41566, Republic of Korea.

$8{ }^{2}$ School of Bioscience and Veterinary Medicine, University of Camerino, 62032 Camerino,

9 Marche - Floristic Research Center of the Appennines, Gran Sasso and Monti della Laga National

10 Park, San Colombo, 67021 Barisciano, L'Aquila, Italy.

$11{ }^{3}$ Ecology Group, Department of Biology, School of Arts and Sciences, National University of

12 Mongolia, Ulaanbaatar 14201, Mongolia.

$13{ }^{4}$ Environmental Department, Oyu Tolgoi LLC, Oyu Tolgoi Site, South Gobi Province, Mongolia.

$14{ }^{5}$ Department of Biological Sciences, Faculty of Science, University of Alberta, Edmonton, Alberta, 15 T6G 2E9 Canada.

$16{ }^{6}$ Centre for Agri-Environmental Research, School of Agriculture, Policy and Development, 17 University of Reading, Reading RG6 6AR, United Kingdom.

$18{ }^{7}$ School of Geographic and Oceanographic Sciences, Nanjing University, Nanjing 210008, 19 China.

$20 *$ Correspondence:

21 Jonathan M. Adams: School of Geographic and Oceanographic Sciences, Nanjing University, 22 Nanjing 210008, China. Tel: (+44) 7504853655 
23 Email: foundinkualalumpur@yahoo.com

24

25 Bazartseren Boldgiv: Ecology Group, Department of Biology, School of Arts and Sciences,

26 National University of Mongolia, Ulaanbaatar 14201, Mongolia. Tel/Fax: (976-11) 325435

27 Email: boldgiv@num.edu.mn

28

29 Conflict of interest:

30 The authors declare no conflict s of interest. 


\section{Abstract}

32 The soil fungal ecology of the southern Gobi region of Mongolia has been little studied. We

33 utilized the ITS1 region from soil DNA to study possible influences on soil fungal community 34 variation. In the sample network, a distinctive fungal community was closely associated with high 35 zinc $(\mathrm{Zn})$, lead $(\mathrm{Pb})$ and copper $(\mathrm{Cu})$ concentrations. The pattern of occurrence suggests that high 36 metal concentrations are natural and not a product of mining activities. The metal-associated 37 fungal community differs little from the 'normal' community in its major OTUs, and in terms of 38 major fungal guilds and taxa, and its distinctiveness depends on a combination of many less 39 common OTUs. The fungal community in the sites with high metal concentrations is no less 40 diverse than in areas with normal background levels. Overall, these findings raise interesting 41 questions of the evolutionary origin and functional characteristics of this apparently 'metal tolerant' 42 community, and of the associated soil biota in general. It is possible that rehabilitation of metal43 contaminated mined soils from spoil heaps could benefit from the incorporation of fungi derived 44 from these areas.

45 Keywords: Fungi, Gobi desert, Heavy metals, Metagenetics, Soil metal, ITS1 region 


\section{Introduction}

47 Heavy metals occur widely in the parent materials of soils at concentrations that are broadly

48 dependent on lithology. During pedogenesis metals become enriched or depleted in different soil

49 horizons, depending on the soil-forming environment and the predominant chemical reactions for

50 each element [1]. Soil may be naturally enriched in metals due to the influence of the underlying

51 geology and the subsequent soil forming and ecological processes, for example, through pedogenic

52 activities in ultramafic and serpentinised geologies (e.g. [2]) or enrichment in the surface horizons

53 following plant uptake from depth (e.g. for $\mathrm{Cu}$ and $\mathrm{Pb}$ see $[3,4])$.

54 Soils with high concentrations of metals are associated with a distinctive microbial communities.

55 This association is not in itself novel: there is abundant evidence of distinctive communities of

56 plants and bacteria associated with metal-rich areas in other parts of the world. Examples include

57 lead-, zinc- and [5] copper-rich mine spoil heaps in the UK and natural serpentine rock areas such

58 as California and Borneo [5, 6]. Soil bacteria have been found to develop metal tolerance under

59 laboratory conditions, by enabling energy dependent efflux of metal ions [7-9]. While metal-rich

60 soils have occasionally been sampled by culturing individual fungal strains from them [10], there

61 are few studies on whole metal-tolerant communities of soil fungi from anywhere in the world.

62 Fungi are known to tolerate and detoxify metals by several mechanisms including valence

63 transformation, extra- and intracellular precipitation and active uptake [11, 12]. Biological

64 mechanisms implicated in fungal survival include extracellular precipitation, transformation of

65 metals, biosorption to cell wall and pigments, decreased transport or impermeability, efflux,

66 intracellular compartmentalization and sequestration [12-14].

67 The behaviour and occurrence of naturally occurring trace elements in the ecology of the soil are

68 complex and the key metals that might influence microbial communities are poorly understood. 
The present study was conducted in a naturally metal-rich area of the Gobi, a large cold desert in

70 southern Mongolia and northern China. The desert basins of the Gobi are bounded by the Altai

71 Mountains and the grasslands and steppes of Mongolia on the north, by the Tibetan Plateau to the

72 southwest, and by the North China Plain to the southwest. It is the fifth largest desert in the world

73 and the largest in Asia [15]. The climate is continental, characterized by dry and cold winters and

74 a precipitation maximum in summer [16]. Our sampling was located in Oyu Tolgoi region, which

75 is situated in the South Gobi desert, Mongolia. This area has only recently been discovered to be

76 rich in metals, especially copper [17-20]. Large scale mining for copper started in 2013, with the

77 opening of the Oyu Tolgoi mine [21]. Five major copper deposits that extend over $6 \mathrm{~km}$ in a north-

78 northeast-oriented zone. These occur in a middle to late Paleozoic arc terrain and are related to

79 Late Devonian quartz monzodiorite intrusions. The Hugo Dummett deposits are the northernmost and deepest, with up to 1,000 m of premineral sedimentary and volcanic cover rock remaining [17].

81 The area is characterized by sparse vegetation and large tracts of Quaternary sediments and loess.

82 Ephemeral streams cross the area and flow for a few short periods during an average summer.

83 Temperatures at Oyu Tolgoi range from $+36^{\circ} \mathrm{C}$ to $-25^{\circ} \mathrm{C}$. Total precipitation is approximately 100

$84 \mathrm{~mm} /$ year and occurs mainly in late spring and early summer [22]. Given the potential ecological

85 sensitivity of this area, several months after the opening of Oyu Tolgoi we undertook a baseline

86 study of the area within a $130 \mathrm{~km}$ radius of the mine. Given the known concentration of natural

87 copper deposits in the southern Gobi, we specifically examined whether metal content is a key

88 factor in the structure and composition of soil fungal communities in this area. This paper mainly

89 aims to critically appraise apparent associations between metal-rich soils and fungal communities

90 in SE Gobi to characterize these communities, and to consider their broader implications for

91 microbial ecology and the study of metal enriched environments. 


\section{Methodology}

\section{$94 \quad 2.1 \quad$ Site description}

95 The sampling area (Supplementary Fig. S1) is located in south-eastern Mongolia, close to the

96 border with China, between the latitudes of $42^{\circ} 31 \mathrm{~N}$ to $43^{\circ} 36 \mathrm{~N}$ and longitudes of $106^{\circ} 34 \mathrm{E}$ to

$97108^{\circ} 10$ E. Samples were taken in mid-September 2013, towards the end of the vegetation growing 98 season.

99 This study commissioned by the Oyu Tolgoi mine company was initially intended to establish 100 reference data for the background state of the soils in this area for future monitoring of any effects 101 of dust contamination, ground water alteration, or displacement of grazing in the area surrounding 102 the mine. For this baseline study of soil chemistry and biota, we sampled a network of 34 sites 103 (Supplementary Table S2) chosen to represent the range of natural vegetation types of the south104 eastern Gobi. Thirty four separate 1 ha plot sample sites were assigned within a radius of $130 \mathrm{~km}$ 105 of the Oyu Tolgoi mine, their positions chosen by selecting representative examples of different 106 habitat types found in the Gobi, based on both local knowledge and on satellite imagery. 107 Vegetation coverage consisted of small shrubs (mostly Chenopodiaceae and Asteraceae) and 108 bunch grasses, with overall plant coverage on the hectare scale varying from $50 \%$ to $70 \%$ 109 (Supplementary Table S1). Common representative plant species are Eurotia ceratoides, 110 Potaninia mongolica and Caragana korshinskii. In each sampling site, we took one subsample at 111 each corner of a hectare square and another in the center. Each subsample consisted of a core, 5 $112 \mathrm{~cm}$ deep and $2 \mathrm{~cm}$ in diameter. The 5 subsamples were combined into one composite sample, 113 mixed thoroughly, and brought back to the laboratory on the same day. Half of the mixed sample 

analysis.

116 In most of the 1 ha plots, vegetation composition was recorded, with a species inventory of all 117 vascular plants present. Due to time limitations, we were unable to make a species inventory of 118 four of the plots.

\subsection{Chemical Analysis and DNA extraction}

121 Soil analyses were carried out in the Laboratory of Soil Science of the Institute of Geography, 122 Mongolian Academy of Sciences, using standard protocols of the Soil Science Association of 123 America (SSSA) [23]. Measured chemical parameters were $\mathrm{pH}, \mathrm{CaCO}_{3}$, total organic carbon 124 (TOC), soil salinity (measured as electric conductivity, dS/m), nitrogen (N), soil texture (TX), 125 chrome $(\mathrm{Cr})$, lead $(\mathrm{Pb})$, cadmium $(\mathrm{Cd})$, copper $(\mathrm{Cu})$ and zinc $(\mathrm{Zn})$. All samples were transported 126 to the laboratory at Oyu Tolgoi mine and frozen at $-20^{\circ} \mathrm{C}$ within 3 hours of sampling. Within days

127 frozen soils were processed for DNA extraction in the Laboratory of Ecological and Evolutionary 128 Synthesis of the National University of Mongolia. Soil was sieved with a $3 \mathrm{~mm}$ sieve, and $0.35 \mathrm{~g}$ 129 of the sieved soil was DNA extracted using the Power Soil DNA extraction kit (MoBio 130 Laboratories, Carlsbad, CA, USA) according to the manufacturer's protocol.

\section{$132 \quad 2.3 \quad$ PCR and sequencing}

133 All the extracted DNA samples were amplified for ITS1 region by using the primer pair ITSIF (5'134 CTTGGTCATTTAGAGGAAGTAA-3') and ITS2 (5'-GCTGCGTTCTTCATCGATGC-3') [24, 135 25]. Polymerase chain reactions (PCR) were performed in $50 \mu$ l reactions using the following 
kit (Qiagen, CA, USA), and sequenced using Illumina Miseq platform (paired end of $2 \times 300$ ) at Macrogen Incorporation (Seoul, Korea), following standard Illumina sequencing protocols [26].

\subsection{Sequence processing}

142 Miseq Illumina [24] sequence data were processed using Mothur platform [27]. In brief, the 143 sequence data were pair assembled using make.contigs and the quality control was performed by 144 identifying chimeric sequence via UCHIME [28] and by filtering chimera sequences. Operational 145 Taxonomic Units (OTUs) were picked using UCLUST [29] with a threshold of 97\% pairwise 146 identity using the QIIME implementation [30]. This cut-off has often been used in fungal 147 community analyses $[31,32]$. After the process, singletons were screened in Mothur. Taxonomic 148 classification was assigned using the UNITE database [33] using the classify command in Mothur. 149 All of the ITS1 sequence data are available under the MG-RAST [34] project ID 17045 150 (http://metagenomics.anl.gov/linkin.cgi?project=17045). The FUNGuild were used to classify 151 OTUs into trophic categories [35].

\subsection{Statistical analysis}

154 To perform the statistical analysis, all samples were standardized by random subsampling to 15513,957 reads per sample. We used a t-test for normal data and Wilcoxon rank-sum test for nonnormal data in $\mathrm{R}$ software package 2.15.2 to test whether the relative abundances of taxonomical

157 groups were significantly different between samples in low metals sites and high metals sites. 
158 OTUs richness and diversity indices were estimated using Mothur. To assess the correlation 159 between richness/diversity and environmental variables, linear regression was performed in 160 SigmaPlot v 10.0 (Systat Software, San Jose, CA). To test for spatial autocorrelation of the fungal 161 community OTU composition, we used the Mantel test (Mantel Nonparametric Test Calculator 162 2.0) [36] to compare matrices of fungal community composition in relation to geographic distance 163 between different samples.

164 An indicator species analysis [37-39] was performed using package labdsv [40] in R software to 165 identify those OTUs that are characteristics of each high and low metal-enriched sites. We used 166 the INDVAL analysis, which identifies indicator species based on OTU fidelity and relative 167 abundance [39]. Only OTUs with significant $(P<0.05)$ and INDVAL values that were $>0.5$ were 168 considered as significant threshold for habitat specialization. The indicator species are defined as 169 the most characteristic species of each group, found mostly in a single group and present in the 170 majority of the samples belonging to that group. Bray-Curtis distance was calculated to analyze 171 fungal community similarity. To reduce the contribution of highly abundant OTUs in relation to 172 less abundant ones in the calculation of Bray-Curtis matrix, abundance data of OTUs were square 173 root transformed. The pairwise differences in fungal community composition were calculated by 174 analysis of similarity (ANOSIM) in relation to Bray-Curtis distance. A constrained analysis was 175 conducted using CANOCO [41] to assess the effect of environmental variables on the fungal 176 community. Forward selection was used in redundancy analysis (RDA) [42] to select significant 177 explanatory variables with 999 permutations and only significant variables $(P<0.05)$ were 178 included in the models.

179 Fungal functional guilds were assigned according to Nguyen et al. [35] and Tedersoo et al. [43] 180 using an open annotation tool (FUNGuild). Here, we only accepted the guild assignment where 
181 confidence ranking was "probable" or "highly probable", as recommended by Nguyen et al. [35].

182 The functional guilds of fungi detected in this study principally included three major functional 183 groups: pathogens, saprotrophs and symbionts

\section{$1853 \quad$ Results}

186 The soils in all sites were alkaline, (mean $\mathrm{pH} 8.7$; range $\mathrm{pH} 8.2-9.3$ ), and contained on average $18756 \%$ of sand, $34 \%$ of silt and $11 \%$ of clay. Results of soil physico-chemical analysis are shown in 188 Supplementary Table S2. In several samples, Zn metal concentrations exceeded EPA, Eco-SSL 189 regulation (http://www.epa.gov/ecotox/ecossl/index.html) levels of $50 \mathrm{mg} / \mathrm{kg}$, reaching $233 \mathrm{mg} / \mathrm{kg}$ in some samples. $\mathrm{Cu}$ and $\mathrm{Pb}$ contents were also above Eco-SSL, EPA level of $50 \mathrm{mg} / \mathrm{kg}$ in some 191 samples, the highest metal concentrations measured were around $2300 \mathrm{mg} / \mathrm{kg}$ for $\mathrm{Cu}$ and 130 $192 \mathrm{mg} / \mathrm{kg}$ for $\mathrm{Pb}$ (Fig. 1). In combination, the combined $\mathrm{Pb}, \mathrm{Zn}$ and $\mathrm{Cu}$ concentration averaged around $193689.78 \mathrm{mg} / \mathrm{kg}$ (ranging from $54.7 \mathrm{mg} / \mathrm{kg}$ to $3061 \mathrm{mg} / \mathrm{kg}$ ).

194 From the 34 soil DNA samples, we obtained a total of 2,459,044 quality reads, which were 195 classified into 11,559 OTUs at the 97\% similarity level. In presentation of results, we have 196 distinguished 'high metal concentration' samples as those containing $>50 \mathrm{ppm} \mathrm{Zn}, \mathrm{Cu}$ and/or $\mathrm{Pb}$.

197 The fungal community averaged across all the samples was dominated by Ascomycota, with 79\% 198 of total reads (Fig. 2a). Basidiomycota was the next most abundant group with $7 \%$ of the total 199 reads. Relative abundance of other phyla was under $1 \%$. There was no significant difference at the 200 phylum level when high metal samples and low metal samples were compared, with the exception 201 of certain minor phyla representing less than $1 \%$ of total reads - including Blastocladiomycota $202(\mathrm{w}=77, \mathrm{P}=0.02)$, Chytridiomycota $(\mathrm{w}=198, \mathrm{P}=0.007)$, Incertae sedis $(\mathrm{w}=62, \mathrm{P}=0.01)$ and 203 Streptophycophyta $(\mathrm{w}=172, \mathrm{P}=0.01)$. 
Among the detected fungal classes, Dothideomycetes and Sordariomycetes (Ascomycota) were the most abundant, with a relative abundance of $48 \%$ and $25 \%$ of reads respectively amongst all samples combined. Tremellomycetes (Basidiomycota) represented 5\% of total reads, and

207 Eurotiomycetes (Ascomycota) and Agaricomycetes (Basidiomycota) were each at around 1\% of total reads. Dominant orders were Pleosporales (46\%), Hypocreales (21\%), Filobasidiales (5\%) 209 and Sordariales (4\%) (Fig. 2b).

210 As Fig. 2c shows, 9 families (These families included Nectriaceae (18\%), Pleosporaceae (17\%), 211 Pleosporales family Incertae sedis (15\%), Sporormiaceae (10\%), Filobasidiaceae (5\%), 212 Chaetomiaceae (2\%), Leptosphaeriaceae (2\%), Lasiosphaeriaceae (1.5\%) and Hypocreales 213 family Incertae sedis (1\%) made up less than $1 \%$ of the total community. Community composition 214 at the family level did not vary in relation to metal content.

215 The most abundant genus across all the samples combined was Gibberella from the family 216 Nectriaceae, representing $18 \%$ of total reads (Fig. 2d). Metal content had no statistically 217 significant effect on genus level composition of the community (Supplementary Table S3).

218 Linear regression analysis showed that metal content had no significant effect on fungal diversity. 219 Similarly, the other soil parameters $(\mathrm{pH}$, soil texture, etc) did not influence the fungal diversity 220 (Supplementary Fig. S2). The effect of metal content on fungal richness and diversity was further 221 evaluated using multiple regression analyses. Metal content (i.e. $\mathrm{Zn}, \mathrm{Pb}$ and $\mathrm{Cu}$ ) did not show any 222 correlation with OTU richness and with diversity indices (Supplementary Fig. S3).

223 Fungal diversity in the high metal samples was no lower than the normal metal samples 224 (Supplementary Fig. S2). The heat map analysis of the 50 most abundant OTUs did not show any 225 consistent difference between high metal and low metals sites, despite the difference of metal 226 concentrations (Supplementary Fig. S4). 
227 Indicator species analysis revealed fungal OTUs that sort between low and high metal sites. The

228 OTUs classified as core community in the low metal samples were represented by 25 genera, and

229 characterized by the genera Phoma (represented by the species Phoma bulgarica, Phoma 230 calidophila, and Phoma sp P31E4), Preussia, Giberella, etc. There were 30 genera classified as 231 core community in high metal samples represented most abundantly by an unclassified fungal 232 genus previously detected in eastern US forest soils by [44] under the name species fungal sp. 38 233 CC 06 28. Also members of the genera Cochliobolus, Curvularia and Chaetomium are abundant 234 examples of the core community of the metal rich sites (Table 1).

235 Vegetation cover $(\mathrm{w}=44.5, P=0.33)$ and plant species composition $(\mathrm{t}=-2.005, \mathrm{df}=6.65, P=0.08) \mathrm{did}$ 236 not differ in relation to any measured soil characteristic among the 30 quadrat samples which had 237 vegetation data (Supplementary Fig. S5). Multiple regression analysis showed that vegetation 238 cover was not correlated with either $\mathrm{Zn}$ soil content, or $\mathrm{Cu}$ soil content $(P>0.05)$, whereas it 239 significantly correlated with $\mathrm{Pb}$ soil content (Supplementary Fig. S6).

240 An RDA (Fig. 3) showed that metal concentration ( $\mathrm{Zn}, \mathrm{Cu}, \mathrm{Pb}$ individually, or all three combined) 241 was the strongest predictor of variation in fungal community composition among our samples. 242 Higher metal content samples (defined in Fig 3 as >200 mg/Kg of $\mathrm{Zn}$ ) tended to cluster separately 243 in terms of fungal community composition (Fig 3). Together with two axes on the biplot, in an 244 accumulative variance for the interaction between communities and variables, a total of $19.3 \%$ of 245 variation was explained. Axis 1 explained $12.2 \%$ of the variation in the data, while axis 2 explained 246 15.8. Among the measured physico-chemical factors, $\mathrm{Zn}$ (pseudo-F=3.7, $P=0.001$ ), $\mathrm{Pb}$ (pseudo$247=1.3, P=0.05$ ) and silt (pseudo-F=2.0, $P=0.001$ ) were significant contributors to fungal 248 community variability, and a forward test indicated that the most important factor was $\mathrm{Zn}$. 
ANOSIM performed on Bray-Curtis community matrix confirmed that samples from low metal content sites and high metal content sites varied significantly from each other (Global $\mathrm{R}=0.48$; $P=0.001)$. The Mantel test showed no effect of spatial distance on the composition of fungal communities amongst the sites (Mantel statistic $r=0.091, P=0.15$ ).

Fungal taxonomic functional analysis by FUNGuild categorized the fungal sequences into different trophic modes. $34 \%$ of all reads were identified as pathotroph, followed by pathotrophsymbiotroph (23\%), saprotroph (19\%), pathotroph-saprotroph (7\%), and less than $1 \%$ for symbiotroph, saprotroph-symbiotroph and pathogen-symbiotroph (Fig. 4a). In this functional study, there was only significant difference in pathogen-symbiotroph (that represents less than $1 \%$ of total trophic modes) between the normal and high rich metal samples. There was no significant difference in trophic strategy composition between samples having normal metal content and samples having high metal content (Fig. 4b).

\section{Discussion}

\subsection{Community characteristics and comparison with other arid environments}

The soil fungal community across all our sampled sites in the Gobi was dominated by Ascomycota, with a much lower abundance of Basidiomycota and other phyla (Fig. 2a). This bias towards Ascomycota is typical of arid environments globally - whereas Basidiomycota normally dominate in forest soils [27, 45-48]. Within the phylum Ascomycota, the most abundant family across all samples was Nectriaceae (18\% of total reads), which includes a number of common pathogens, but also saprobes [49]. Within this family, the genera Gibberella and Fusarium which contain both plant pathogens and saprobes [50-54] were at $18 \%$ and $1 \%$ relative abundance, respectively (Fig. 2d). This again is typical of arid environments: for example Fusarium is generally one of the 
272 commonest fungi in desert environments globally, and members have often been found to be 273 abundant in the presence of metals [55, 56].

274 The family Pleosporaceae (Ascomycota) was also very abundant in our samples (17\% of total 275 reads). Members of this group are typically necrotrophic pathogens and saprobes, especially 276 associated with grasses [49]. Within the family, the genera Mycocentrospora (11\% of total reads) 277 and Alternaria (10\% of total reads) were particularly abundant in these Gobi sites. Alternaria has 278 also been isolated from the metal-rich soils elsewhere [56, 57]. Mycocentrospora forms 279 chlamydospores which have thick walls for surviving in extreme environments, a feature that may 280 allow it to live in the very variable water environment of the Gobi [57].

281 The most abundant family of Basidiomycota in our samples was Filobasidiaceae, belonging to the 282 order Filobasidiales and the class Tremellomycetes. Their mean relative abundance was $4.8 \%$, and 283 they made up most of the Basidiomycota in these samples (the Basidiomycota averaging in total 284 at $7 \%$ of reads). Genus Cryptococcus under family Filobasidiaceae is also known to exhibit 285 tolerance to $\mathrm{Cu}$ and $\mathrm{Zn}$ [48]. Filobasidiaceae have been isolated from Antarctic ecosystems and 286 have a very wide range of habitats. The relative abundance of Basidiomycota was much less than 287 in typical samples in forested or damper environments, but typical of semi-arid and arid locations: 288 generally Basidiomycota are less abundant in hot desert environments [49].

289 In terms of trophic guilds from FUNGuild, pathotrophism was the most abundant category with $29034 \%$ of total fungal reads, although this may reflect the difficulties of guild assignment in very 291 diverse genera such as Giberella and Fusarium known to contain saprobes [58]. Pathotroph292 symbiotrophism was the second abundant trophic mode with $23 \%$ of total reads. Saprotrophism 293 was the third most abundant category overall, at $19 \%$ of total reads, which agrees with the family 294 level results discussed above. The spore-forming habit of many saprotrophs may allow their 
295

296

297

298

299

300

301

302

303

304

305

306

307

308

309

310

311

312

313

314 include the 'indicator' taxa mentioned above.

315 It is of course necessary to ask if the close relationship we observed between metal concentrations

survival in mostly dry soils without any physiological activity $[58,59]$.The least abundant trophic category was saprotroph-symbiotroph, accounting for only $0.2 \%$ of reads (Fig. 4).

\subsection{Community patterns in relation to metal content}

In the RDA for the Gobi plots, the community divides very clearly into two clusters (Fig. 3). There is clear tendency in the RDA for the metal rich samples (average $\mathrm{Zn}$ concentration in metal samples of $225.44 \mathrm{mg} / \mathrm{kg}, 1500 \mathrm{mg} / \mathrm{kg} \mathrm{Cu}$ and $70.39 \mathrm{mg} / \mathrm{kg} \mathrm{Pb}$ ) to cluster on one side of the ordination diagram, with variation in fungal community composition mainly related to metal concentrations (Fig. 3), and with $\mathrm{Zn}$ and $\mathrm{Pb}$ as the strongest predictors.

The RDA analysis shows a strong consistent pattern in relation to metals, especially $\mathrm{Zn}$ and $\mathrm{Pb}$. Despite the clear differentiation of the fungal community by soil metal content on the RDA ordinations, at the broad taxonomic level the composition of the metal-poor and the metal-rich communities at the phylum, class and family level is very similar (Fig. 2). The same dominant genera are also found in all samples, both metal-rich and normal (Fig. 2d). Comparing the heat maps of metal-poor and metal-rich samples, there is no clearly evident community difference in terms of the 50 most abundant OTUs shown (Supplementary Fig. S4). The same major OTUs are present across both sample sets. Whatever the differences that lead to the high metal samples clustering separately, they presumably involve either the overall effect of many rarer OTUs, or consistent but subtle differences in the abundance of both common and rare OTUs. These OTUs and fungal community composition is merely spurious, with these factors inter-correlating with some other soil parameters that actually play the important role in determining soil fungal 
community composition. Since a broad range of soil parameters was measured (Supplementary

319 Table $\mathrm{S} 2$ ) and $\mathrm{Zn}, \mathrm{Pb}$ and $\mathrm{Cu}$ were by far the best predictors of fungal community variation (Fig.

320 3), it seems unlikely that metal concentrations are merely a proxy for other soil parameters. This

321 agrees with is a generally accepted view that high metal concentrations may lead to alteration of

322 soil microbial community structure $[61,62]$.

323 The 'high' metal concentrations $(\mathrm{Zn}, \mathrm{Pb}$ and $\mathrm{Cu})$ seen here in some of our samples are not 324 exceptionally high compared to some contaminated sites studied in Europe which have had around

32510 times this concentration [63]. However, in their experimental studies Smolders et al. (2004)

326 observed effects of $\mathrm{Zn}$ on soil microbial (mostly bacterial) activity starting at concentrations

327 around $200 \mathrm{mg} / \mathrm{kg}$ of $\mathrm{Zn}$, similar those we observed, which suggests that at the concentrations

328 found in the Gobi sites, microbial ecology could be significantly affected by $\mathrm{Zn}$ and other metals.

329 A background of previous work also suggests that soil fungi are especially susceptible to high $\mathrm{Zn}$

330 concentrations, compared to bacteria. A study by Speir et al. [65] found that increasing $\mathrm{Zn}$

331 concentrations between 0 and $400 \mathrm{mg} / \mathrm{kg}$ had a significant negative impact on enzymatic activities

332 of soil fungi (in our study the higher metal sites had around $200 \mathrm{mg} / \mathrm{kg}$ of $\mathrm{Zn}$ ). Soil fungal

333 communities have been found to be more responsive to $\mathrm{Zn}$ than soil bacteria are [60, 66]. Most of

334 the samples that cluster at the higher end in terms of $\mathrm{Zn}$ concentrations greatly exceed

335 environmental tolerance guidelines for $\mathrm{Zn}$ (EPA, Eco-SSL database:

336 http://www.epa.gov/ecotox/ecossl/index.html, Supplementary Table S2) and the concentration

337 limits reported in Kabata-Pendias [67] who stated that the threshold upper limit value of $\mathrm{Cu}$ in

338 surface soils should be around $100 \mathrm{ppm}$, whereas our most $\mathrm{Cu}$ rich soils have concentrations of an 339 average of $1475 \mathrm{ppm}$. They also noted that upper limit for the $\mathrm{Pb}$ content is around $70 \mathrm{ppm}$ whereas 340 our most $\mathrm{Pb}$ rich soils have an average concentrations of $66 \mathrm{ppm}$, and the mean $\mathrm{Zn}$ for worldwide 
341 soils is around $64 \mathrm{ppm}$, whereas our most of our Zn soils have concentrations of an average of 224

$342 \mathrm{ppm}$. This is certainly suggestive that toxicity may have a role in selecting the distinctive 343 community that is found in these places. In some previous studies, soil fungi were found to be 344 more sensitive to $\mathrm{Cu}$ than $\mathrm{Zn}$ and tended to have tolerance of $\mathrm{Zn}[68,69]$.

345 It is also necessary to consider the possibility that the summative effect of multiple metals in the 346 soil may be having the observed effect on fungal communities. It may also be important that the 347 metals in our sampled soils tend to co-occur at higher concentrations. In recent years, there has 348 been growing awareness of the interactive effects that multiple metals may have on soil ecology. 349 This phenomenon, known as mixture toxicity, takes place where synergies between metals arise $350[70,71]$. Synergistic effects occur when the combined effect of two metals is greater than the sum 351 of the effect of each metal individually. For synergistic interactions to occur in the soil, interacting 352 metals have both to co-occur and to be present at concentrations high enough to induce the synergy $353[72,73]$. It is plausible, given that $\mathrm{Zn}, \mathrm{Pb}$ and $\mathrm{Cu}$ in our soils are strongly co-occurring, there is a 354 synergistic effect at work here in affecting the soil community.

An important proviso on the case that metal ions are a major direct factor in the fungal 356 ecology of this area, however, is that the soil $\mathrm{pH}$ in the metal-rich areas is high, and that this is 357 predicted to limit bioavailability of metal ions $[74,75]$. In general - based on idealized laboratory 358 observations of the chemistry and solubility of metal salts - each unit increase in $\mathrm{pH}$ is forecast to 359 result in halving of available concentrations [75-78]. As the average $\mathrm{pH}$ of the soils which 360 contained high metals was 8.66 , having a pH range between 8.43 to 8.87 (Supplementary Table $361 \mathrm{~S} 2$ ), the actual bioavailability would be predicted to be lower than in neutral or acidic soils [79, 362 80]. Exactly how much soil $\mathrm{pH}$ affects metal ion availability in actual soils is uncertain: Smolders 363 et al. [63] found that over a range of $\mathrm{pH}$ from 4.5 to $7.5, \mathrm{Zn}$ toxicity effects on soil microbes were 
unaffected by $\mathrm{pH}$, suggesting that the theoretical limits are inaccurate. All that one can really state

365 is that while correlation suggests that $\mathrm{Zn}, \mathrm{Cu}$ and $\mathrm{Pb}$ are affecting the fungal communities in the

366 Gobi, traditional inorganic chemistry predicts that their effects are weaker than they would be if

367 soil $\mathrm{pH}$ were more acidic. Protection against toxic effects of metals in soils can also occur through

368 various other mechanisms: for example organic matter content, clay content and iron oxide content

$369[78,81-83]$, and it is possible that these too affect the biological availability of $\mathrm{Zn}$ and other metals

370 in the soil.

371

$372 \quad 4.3$ Community patterns in relation to vegetation

373 Vegetation composition and percentage coverage did not correlate with fungal community 374 composition in the sampled areas. Despite the apparent effects of these metals on the fungal 375 community, the visual appearance of the Gobi ecosystem in the high metal areas does not suggest 376 intense toxicity by metals. In the 30 samples which had vegetation data, the plant diversity and 377 vegetation coverage of the most metal-rich 1 ha plots we obtained from the Gobi was no less than 378 the 1 ha plots with normal metal concentrations, suggesting that: 1) the plants themselves have 379 evolved local metal-tolerant ecotypes, 2) there might be evolutionary adaptation by the soil biota, 380 perhaps in sequestering metal ions (and possibly making these metal ions unavailable to the plants 381 in the process) or 3) due to high $\mathrm{pH}$ in limiting availability, the effects of high $\mathrm{Zn}$ or $\mathrm{Cu}$ or $\mathrm{Pb}$ 382 concentrations are marginal in terms of plant growth and ecosystem function, despite a subtle 383 effect that can be detected in ordination of the fungal community.

\subsection{High diversity of the metal-rich soil fungal communities}


Despite the high concentrations of metals in some of the soils, and the apparently dominant role of metal concentrations in determining variation in fungal community structure, the diversity of soil fungi in the metal-rich 1 ha plot samples was no less than in the local soils with normal background levels of metals (Supplementary Fig. S2).

Extreme environments are usually seen as being associated with lower diversity [84]. This is the case for example with soil bacterial communities of metal-polluted soils, and of extreme high and low $\mathrm{pH}$ conditions [85-88]. However, in a previous study of the effects of application of sewage sludge rich in metals, similarly high metal concentrations in soils still only showed minor effects 394 on microbial diversity [60].

In the system we are studying here, there seems to be no association between diversity and 396 'extreme' conditions (high $\mathrm{Zn}, \mathrm{Cu}$ and $\mathrm{Pb}$ concentrations), for soil fungi at least. It is possible that 397 the high soil $\mathrm{pH}$ acts as a protectant against the worst effects of the metal ions on cell physiology 398 preventing the diversity-suppressing effects normally associated with an extreme environment. 399 Relatively low bioavailability could explain why fungal diversity is comparable with the other soil 400 samples with normal background concentrations of these metals, even though the metal 401 concentration is apparently having enough biological effect to make it a strong predictor of 402 community variation. An alternative, or additional, explanation for why these metal-rich soils 403 remain high in fungal diversity is that high metal concentrations in this area have existed for long 404 geological periods, allowing a very diverse soil fungal community to build up.

\subsection{Are the high metal concentrations natural or influenced by anthropogenic activity?}

407 The source of the $\mathrm{Zn}$ and also the $\mathrm{Cu}$ and $\mathrm{Pb}$ found in many of the sites we sampled is unclear. 408 Most of our more metal-rich sites are found across a broad radius south-east of the Oyu Tolgoi 
mine site, and the predominant wind direction in the area is north-west to south-east [89], which

410 could imply that dust from the mine is the source. However, this seems unlikely, as the

411 concentration of $\mathrm{Zn}, \mathrm{Cu}$ and $\mathrm{Pb}$ does not show any relationship with distance from the mine, with

412 some of the most metal rich samples being $20-80 \mathrm{~km}$ or more away from the mine, in areas never

413 before mined. Scattered amongst the metal rich sites were also other sites that have normal

414 background levels of metals, which would not be expected if an extensive metal-rich dust plume

415 was spreading out across the desert. Also, the mine had only recently opened, producing its first

416 ore in 2013 which was the year of sampling [21], which further implies that it is unlikely to have

417 provided such extensive contamination of $\mathrm{Zn}, \mathrm{Cu}$ and $\mathrm{Pb}$ over such a large area, and to have

418 produced any noticeable changes in a fungal community averaged through the sampling depth of

$419 \quad 0-10 \mathrm{~cm}$. Additionally, a further set of very metal rich samples are found $30-40 \mathrm{~km}$ north-east of

420 the mine, well upwind from the mine.

421 The most plausible explanation is that the high soil metal concentrations we observe here in the

422 south eastern Gobi are natural, a consequence of the geological enrichment of rocks in this area

423 with metal ores [90, 91], followed by weathering to form metal-rich soils.

424

\section{Conclusions}

426 The area around Oyu Tolgoi appears to be an unusual system, with naturally high soil

427 concentrations of $\mathrm{Zn}, \mathrm{Cu}$ and $\mathrm{Pb}$ in many areas $[90,91]$. The strength of correlation suggests that

$428 \mathrm{Zn}$ in particular dominates the community composition of soil fungi in this area, although $\mathrm{Cu}$ and

$429 \mathrm{~Pb}$ might also play an important part since they also tend to occur at high concentrations in the

430 same Zn-rich areas. Despite the high metal concentrations, diversity of fungi in the metal-rich 
431 areas is as high as in areas with normal background metal concentrations, which suggests the

432 possibility of a long history of specialized adaptation by the soil biota.

433 As a naturally metal-rich system, the soil ecology of Oyu Tolgoi area deserves further study. It

434 appears to offer a natural analog to anthropogenic metal-contaminated sites associated with

435 industrial activity around the world. Globally, there are very few known examples of naturally

436 metalliferous soil, the few exceptions being serpentine rock outcrops (rich in Ni), and $\mathrm{Zn}$-rich sites

437 in central Europe [5, 92] - but even these are much more localized in extent than the Gobi area

438 that we studied. To our knowledge, no naturally metalliferous soil has ever been thoroughly

439 investigated from a microbial viewpoint. It would be interesting to know what (if any) special

440 adaptations the fungi in these metal-enriched soils have to the presence of metal ions, and whether

441 the distinctive community composition also extends to other soil organisms such as bacteria, soil

442 metazoans and archaea. Further studies should also include the soil metagenome, its

443 metatranscriptome, and soil properties such as potential soil respiration rate. Such aspects could

444 then be compared to those of anthropogenically contaminated sites, for potential lessons in terms

445 of the processes of community adaptation over time, and practical guidance for rehabilitation of

446 contaminated land.

447

448 Acknowledgments

449 This work was supported by the National Research Foundation (NRF) grant funded by the Korean 450 government, Ministry of Education, Science and Technology (MEST) (NRF 2013-031400). We 451 also received logistical support for field work and soil analytical services from the Oyu Tolgoi 452 mining company. DA, OE, SU, BB were also supported by the Taylor Family-Asia Foundation 453 Endowed Chair in Ecology and Conservation Biology. 


\section{References}

456 1. Adriano DC (2001) ArsenicTrace elements in terrestrial environments. Springer, pp. 219261

2. Van Der Ent A, Cardace D, Tibbett M, Echevarria G (2018) Ecological implications of pedogenesis and geochemistry of ultramafic soils in Kinabalu Park (Malaysia). Catena 160: 154-169.

3. Baker D, Senft J (1995) Copper (179-205) i Alloway. BJ (red) Heavy metals in.

4. Alloway B (1995) Cadmium, Ch. 6. Heavy Metals in Soils: London, Blackie: 100-124.

5. Hildebrandt U, Hoef-Emden K, Backhausen S, Bothe H, Bożek M, Siuta A, Kuta E (2006) The rare, endemic zinc violets of Central Europe originate from Viola lutea Huds. Plant Syst Evol 257: 205-222.

6. $\quad$ Ernst WH (2006) Evolution of metal tolerance in higher plants. For Snow Landsc Res 80: 251-274.

7. Diaz-Ravina M, Baath E (1996) Development of metal tolerance in soil bacterial communities exposed to experimentally increased metal levels. Appl Environ Microbiol 62: 2970-2977.

8. Hassen A, Saidi N, Cherif M, Boudabous A (1998) Resistance of environmental bacteria to heavy metals. Bioresour Technol 64: 7-15.

9. Piotrowska-Seget Z, Cycoń M, Kozdroj J (2005) Metal-tolerant bacteria occurring in heavily polluted soil and mine spoil. Appl Soil Ecol 28: 237-246.

10. Zarei M, Hempel S, Wubet T, Schäfer T, Savaghebi G, Jouzani GS, Nekouei MK, Buscot F (2010) Molecular diversity of arbuscular mycorrhizal fungi in relation to soil chemical properties and heavy metal contamination. Environ Pollut 158: 2757-2765.

11. Ashida J (1965) Adaptation of fungi to metal toxicants. Annu Rev Phytopathol 3: 153-174.

12. Gadd GM (1993) Interactions of fungip with toxic metals. New Phytologist 124: 25-60.

13. Ross I (1975) Some effects of heavy metals on fungal cells. Trans Br Mycol Soc 64: 175193.

14. Mehra RK, Winge DR (1991) Metal ion resistance in fungi: molecular mechanisms and their regulated expression. J Cell Biochem 45: 30-40.

15. Magsar U, Baasansuren E, Tovuudorj M-E, Shijirbaatar O, Chinbaatar Z, Lkhagvadorj K, Kwon O (2018) Medicinal plant diversity in the southern and eastern Gobi Desert region, Mongolia. J Ecol Environ 42: 4.

16. An C-B, Chen F-H, Barton L (2008) Holocene environmental changes in Mongolia: a review. Global Planet Change 63: 283-289.

17. Khashgerel B-E, Rye RO, Hedenquist JW, Kavalieris I (2006) Geology and reconnaissance stable isotope study of the Oyu Tolgoi porphyry $\mathrm{Cu}$-Au system, South Gobi, Mongolia. Econ Geol 101: 503-522.

18. Panteleyev A, Eng P (2002) Report on the Geology and Mineral Potential of 'Shivee Tolgoi’Property, Southern Gobi Gold-Copper Belt, Mongolia. Private Report for Entrée Resources Inc.

19. Wainwright AJ, Tosdal RM, Forster CN, Kirwin DJ, Lewis PD, Wooden JL (2011) Devonian and carboniferous arcs of the oyu tolgoi porphyry $\mathrm{Cu}-\mathrm{Au}$ district, South Gobi region, Mongolia. Geol Soc Am Bull 123: 306-328.

20. Suzuki Y (2013) Conflict between mining development and nomadism in MongoliaThe Mongolian Ecosystem Network. Springer, pp. 269-294 
500 21. Miller J (2013) Oyu Tolgoi: A Nation Changer. Eng Min J 214: 68.

501 22. Kirwin D, Forster C, Kavalieris I, Crane D, Orssich C, Panther C, Garamjav D, Munkhbat T, Niislelkhuu G (2005) The Oyu Tolgoi copper-gold porphyry deposits, south Gobi, Mongolia. Geodynamics and metallogeny of Mongolia with a special emphasis on copper and gold deposits SEG-IAGOD field trip: 14-16.

23. Topp GC, Reynolds WD, Green RE (1993) Advances in measurement of soil physical properties: Bringing theory into practice. Soil Sci 156: 429-432.

24. Gardes M, Bruns TD (1993) ITS primers with enhanced specificity for basidiomycetesapplication to the identification of mycorrhizae and rusts. Mol Ecol 2: 113-118.

25. White TJ, Bruns T, Lee S, Taylor J (1990) Amplification and direct sequencing of fungal ribosomal RNA genes for phylogenetics. PCR protocols: a guide to methods and applications 18: 315-322.

26. Grada A, Weinbrecht K (2013) Next-generation sequencing: methodology and application. J Invest Dermatol 133: 1-4.

27. Schoch CL, Sung G-H, López-Giráldez F, Townsend JP, Miadlikowska J, Hofstetter V, Robbertse B, Matheny PB, Kauff F, Wang Z (2009) The Ascomycota tree of life: a phylumwide phylogeny clarifies the origin and evolution of fundamental reproductive and ecological traits. Syst Biol: syp020.

28. Edgar RC, Haas BJ, Clemente JC, Quince C, Knight R (2011) UCHIME improves sensitivity and speed of chimera detection. Bioinformatics 27: 2194-2200.

29. Edgar RC (2010) Search and clustering orders of magnitude faster than BLAST. Bioinformatics 26: 2460-2461.

30. Caporaso JG, Kuczynski J, Stombaugh J, Bittinger K, Bushman FD, Costello EK, Fierer N, Pena AG, Goodrich JK, Gordon JI (2010) QIIME allows analysis of high-throughput community sequencing data. Nat Methods 7: 335.

31. Nilsson RH, Kristiansson E, Ryberg M, Hallenberg N, Larsson KH (2008) Intraspecific ITS variability in the kingdom Fungi as expressed in the international sequence databases and its implications for molecular species identification. Evol Bioinformatics 4.

32. Tedersoo L, Nilsson RH, Abarenkov K, Jairus T, Sadam A, Saar I, Bahram M, Bechem E, Chuyong G, Kõljalg U (2010) 454 Pyrosequencing and Sanger sequencing of tropical mycorrhizal fungi provide similar results but reveal substantial methodological biases. New Phytol 188: 291-301.

33. Abarenkov K, Henrik Nilsson R, Larsson KH, Alexander IJ, Eberhardt U, Erland S, Høiland K, Kjøller R, Larsson E, Pennanen T (2010) The UNITE database for molecular identification of fungi-recent updates and future perspectives. New Phytol 186: 281-285.

34. Meyer F, Paarmann D, D'Souza M, Olson R, Glass EM, Kubal M, Paczian T, Rodriguez A, Stevens R, Wilke A (2008) The metagenomics RAST server-a public resource for the automatic phylogenetic and functional analysis of metagenomes. BMC bioinformatics 9: 386.

35. Nguyen NH, Song Z, Bates ST, Branco S, Tedersoo L, Menke J, Schilling JS, Kennedy PG (2016) FUNGuild: an open annotation tool for parsing fungal community datasets by ecological guild. Fungal Ecol 20: 241-248.

36. Liedloff A (1999) Mantel nonparametric test calculator. School of Natural Resource Sciences, Queensland University of Technology, Queensland, Australia.

37. Bakker JD (2008) Increasing the utility of indicator species analysis. J Appl Ecol 45: 18291835 . 
38. De Cáceres M, Legendre P, Moretti M (2010) Improving indicator species analysis by combining groups of sites. Oikos 119: 1674-1684.

39. Dufrêne M, Legendre P (1997) Species assemblages and indicator species: the need for a flexible asymmetrical approach. Ecol Monogr 67: 345-366.

40. Roberts DW (2007) labdsv: Ordination and multivariate analysis for ecology. R package version 1.

41. S Šmilauer P, Lepš J (2014) Multivariate analysis of ecological data using CANOCO 5. Cambridge university press

42. Ter Braak CJ (1986) Canonical correspondence analysis: a new eigenvector technique for multivariate direct gradient analysis. Ecology 67: 1167-1179.

43. Tedersoo L, Bahram M, Põlme S, Kõljalg U, Yorou NS, Wijesundera R, Ruiz LV, VascoPalacios AM, Thu PQ, Suija A (2014) Global diversity and geography of soil fungi. Science 346: 1256688.

44. Baird R, Stokes CE, Wood-Jones A, Alexander M, Watson C, Taylor G, Johnson K, Remaley T, Diehl S (2014) Fleshy Saprobic and Ectomycorrhizal Fungal Communities Associated with Healthy and Declining Eastern Hemlock Stands in Great Smoky Mountains National Park. Southeast Nat 13: 192-219.

45. Buee M, Reich M, Murat C, Morin E, Nilsson RH, Uroz S, Martin F (2009) 454 Pyrosequencing analyses of forest soils reveal an unexpectedly high fungal diversity. New Phytol 184: 449-456.

46. Matsushita Y, Bao Z, Kurose D, Okada H, Takemoto S, Sawada A, Nagase H, Takano M, Murakami H, Koitabashi M (2015) Community structure, diversity, and species dominance of bacteria, fungi, and nematodes from naturally and conventionally farmed soil: a case study on Japanese apple orchards. Organic Agriculture 5: 11-28.

47. Wang H, Guo S, Huang M, Thorsten LH, Wei J (2010) Ascomycota has a faster evolutionary rate and higher species diversity than Basidiomycota. Science China Life Sciences 53: 1163-1169.

48. Vadkertiová R, Sláviková E (2006) Metal tolerance of yeasts isolated from water, soil and plant environments. J Basic Microbiol 46: 145-152.

49. Cannon PF, Kirk PM (2007) Fungal families of the world. Cabi

50. Yoshida N, Sakai Y, Serata M, Tani Y, Kato N (1995) Distribution and properties of fructosyl amino acid oxidase in fungi. Appl Environ Microbiol 61: 4487-4489.

51. Tudzynski B, Hedden P, Carrera E, Gaskin P (2001) The P450-4 gene of Gibberella fujikuroi encodes ent-kaurene oxidase in the gibberellin biosynthesis pathway. Appl Environ Microbiol 67: 3514-3522.

52. Tani Y, Mori N, Ogata K, Yamada H (1979) Production and Purification of Choline Oxidase from Cylindrocarpon didymum M-1. Agric Biol Chem 43: 815-820.

53. Malonek S, Rojas M, Hedden P, Gaskin P, Hopkins P, Tudzynski B (2005) Functional characterization of two cytochrome P450 monooxygenase genes, P450-1 and P450-4, of the gibberellic acid gene cluster in Fusarium proliferatum (Gibberella fujikuroi MP-D). Appl Environ Microbiol 71: 1462-1472.

54. Troncoso C, González X, Bömke C, Tudzynski B, Gong F, Hedden P, Rojas MC (2010) Gibberellin biosynthesis and gibberellin oxidase activities in Fusarium sacchari, Fusarium konzum and Fusarium subglutinans strains. Phytochemistry 71: 1322-1331.

55. Bhatnagar A, Bhatnagar M (2005) Microbial diversity in desert ecosystems. Curr Sci 89: 91-100. 
56. Zafar S, Aqil F, Ahmad I (2007) Metal tolerance and biosorption potential of filamentous fungi isolated from metal contaminated agricultural soil. Bioresour Technol 98: 2557-2561.

57. Dix NJ (2012) Fungal ecology. Springer Science \& Business Media

58. Ciccarone C, Rambelli A (2000) A study on micro-fungi in arid areas: notes on soil saprotrophs and animal opportunistic pathogens. Plant Biosyst 134: 25-29.

59. Sterflinger K, Tesei D, Zakharova K (2012) Fungi in hot and cold deserts with particular reference to microcolonial fungi. Fungal Ecol 5: 453-462.

60. Anderson IC, Parkin PI, Campbell CD (2008) DNA-and RNA-derived assessments of fungal community composition in soil amended with sewage sludge rich in cadmium, copper and zinc. Soil Biol Biochem 40: 2358-2365.

61. Frostegård Å, Tunlid A, Bååth E (1996) Changes in microbial community structure during long-term incubation in two soils experimentally contaminated with metals. Soil Biol Biochem 28: 55-63.

62. Bååth E, Díaz-Raviña M, Frostegård Å, Campbell CD (1998) Effect of metal-rich sludge amendments on the soil microbial community. Appl Environ Microbiol 64: 238-245.

63. Smolders E, Buekers J, Oliver I, McLaughlin MJ (2004) Soil properties affecting toxicity of zinc to soil microbial properties in laboratory-spiked and field-contaminated soils. Environ Toxicol Chem: An Inter J 23: 2633-2640.

64. Kim M, Boldgiv B, Singh D, Chun J, Lkhagva A, Adams JM (2013) Structure of soil bacterial communities in relation to environmental variables in a semi-arid region of Mongolia. J Arid Environ 89: 38-44.

65. Speir TW, Van Schaik AP, Hunter LC, Ryburn JL, Percival HJ (2007) Attempts to derive EC 50 values for heavy metals from land-applied $\mathrm{Cu}-, \mathrm{Ni}_{-}$, and $\mathrm{Zn}$-spiked sewage sludge. Soil Biol Biochem 39: 539-549.

66. Macdonald C, Singh B, Peck J, Van Schaik A, Hunter L, Horswell J, Campbell C, Speir T (2007) Long-term exposure to Zn-spiked sewage sludge alters soil community structure. Soil Biol Biochem 39: 2576-2586.

67. Kabata-Pendias A (2010) Trace elements in soils and plants. CRC press

68. Gadd GM (1994) Interactions of fungi with toxic metals. The Genus Aspergillus. Springer, pp. 361-374

69. Blaudez D, Jacob C, Turnau K, Colpaert J, Ahonen-Jonnarth U, Finlay R, Botton B, Chalot M (2000) Differential responses of ectomycorrhizal fungi to heavy metals in vitro. Mycol Res 104: 1366-1371.

70. Yang Z.X, Liu S.Q, Zheng D.W, Feng S.D (2006) Effects of cadium, zinc and lead on soil enzyme activities. J Environ Sci 18: 1135-1141.

71. Wang Y-P, SHI J-y, Qi L, Chen X-c, Chen Y-x (2007) Heavy metal availability and impact on activity of soil microorganisms along a $\mathrm{Cu} / \mathrm{Zn}$ contamination gradient. J Environ Sci 19: 848-853.

72. Cedergreen N (2014) Quantifying synergy: a systematic review of mixture toxicity studies within environmental toxicology. PloS one 9: e96580.

73. Wu X, Cobbina SJ, Mao G, Xu H, Zhang Z, Yang L (2016) A review of toxicity and mechanisms of individual and mixtures of heavy metals in the environment. Environ Sci Pollut Res 23: 8244-8259.

74. Rajapaksha R, Tobor-Kapłon M, Bååth E (2004) Metal toxicity affects fungal and bacterial activities in soil differently. Appl Environ Microbiol 70: 2966-2973. 
75. Wang X, Wei D, Ma Y, McLaughlin MJ (2015) Derivation of soil ecological criteria for copper in Chinese soils. PloS one 10: e0133941.

76. Christensen TH (1984) Cadmium soil sorption at low concentrations: I. Effect of time, cadmium load, $\mathrm{pH}$, and calcium. Water Air Soil Pollut 21: 105-114.

77. Appel C, Ma L (2002) Concentration, $\mathrm{pH}$, and surface charge effects on cadmium and lead sorption in three tropical soils. J Environ Quality 31: 581-589.

78. Bradl HB (2004) Adsorption of heavy metal ions on soils and soils constituents. J Colloid Inter Sci 277: 1-18.

79. Munoz-Melendez G, Korre A, Parry S (2000) Influence of soil pH on the fractionation of $\mathrm{Cr}, \mathrm{Cu}$ and $\mathrm{Zn}$ in solid phases from a landfill site. Environ Pollut 110: 497-504.

80. Wang Y, Shi J, Wang H, Lin Q, Chen X, Chen Y (2007) The influence of soil heavy metals pollution on soil microbial biomass, enzyme activity, and community composition near a copper smelter. Ecotoxicol Environ Safety 67: 75-81.

81. Smolders E, Oorts K, Van Sprang P, Schoeters I, Janssen CR, McGrath SP, McLaughlin MJ (2009) Toxicity of trace metals in soil as affected by soil type and aging after contamination: using calibrated bioavailability models to set ecological soil standards. Environ Toxicol Chem 28: 1633-1642.

82. Babich H, Stotzky G, Ehrlich H (1980) Environmental factors that influence the toxicity of heavy metal and gaseous pollutants to microorganisms. CRC Crit Rev Microbiol 8: 99145.

83. Giller KE, Witter E, Mcgrath SP (1998) Toxicity of heavy metals to microorganisms and microbial processes in agricultural soils: a review. Soil Biol Biochem 30: 1389-1414.

84. Paul EA (2014) Soil microbiology, ecology and biochemistry. Academic press

85. Gans J, Wolinsky M, Dunbar J (2005) Computational improvements reveal great bacterial diversity and high metal toxicity in soil. Science 309: 1387-1390.

86. Shen C, Xiong J, Zhang H, Feng Y, Lin X, Li X, Liang W, Chu H (2013) Soil pH drives the spatial distribution of bacterial communities along elevation on Changbai Mountain. Soil Biol Biochem 57: 204-211.

87. Yanagawa K, Morono Y, de Beer D, Haeckel M, Sunamura M, Futagami T, Hoshino T, Terada T, Nakamura K-i, Urabe T (2013) Metabolically active microbial communities in marine sediment under high-CO2 and low-pH extremes. The ISME J 7: 555-567.

88. Sorokin DY, Berben T, Melton ED, Overmars L, Vavourakis CD, Muyzer G (2014) Microbial diversity and biogeochemical cycling in soda lakes. Extremophiles 18: 791-809.

89. Zhibao D, Xunming W, Lianyou L (2000) Wind erosion in arid and semiarid China: an overview. J Soil Water Conserv 55: 439-444.

90. Khashgerel B-E, Kavalieris I, Hayashi K-i (2008) Mineralogy, textures, and whole-rock geochemistry of advanced argillic alteration: Hugo Dummett porphyry $\mathrm{Cu}-\mathrm{Au}$ deposit, Oyu Tolgoi mineral district, Mongolia. Mineralium Deposita 43: 913-932.

91. Perelló J, Cox D, Garamjav D, Sanjdorj S, Diakov S, Schissel D, Munkhbat TO, Oyun G (2001) Oyu Tolgoi, Mongolia: siluro-devonian porphyry $\mathrm{Cu}-\mathrm{Au}-(\mathrm{Mo})$ and high-sulfidation $\mathrm{Cu}$ mineralization with a cretaceous chalcocite blanket. Econ Geol 96: 1407-1428.

92. Brady KU, Kruckeberg AR, Bradshaw Jr H (2005) Evolutionary ecology of plant adaptation to serpentine soils. Annu Rev Ecol Evol Syst: 243-266. 


\section{$681 \quad$ Figure legends}

682 Fig. 1 Metal $(\mathrm{Zn}, \mathrm{Cu}$ and $\mathrm{Pb})$ contents in low metal samples and high metal samples. High metal 683 is defined by cutoff concentrations of $50 \mathrm{mg} / \mathrm{kg}$ in $\mathrm{Zn}, \mathrm{Pb}$ and $\mathrm{Cu}$.

684 Fig. 2 Relative abundance of the detected fungal taxa observed in the Gobi samples (a) at the 685 phylum level, (b) class level, (c) Family level and (d) genus level.

686 Fig. 3 Redundancy Analysis (RDA) ordination plot of fungal community composition based on 687 ITS1 gene OTUs and a vector overlay of the environmental variables. The significant 688 environmental variables were shown in red arrows. Red dots denote samples having low heavy 689 metal contents and blue dots denote samples having high heavy metal contents.

690 Fig. 4 Detected fungal tropic mode by FUNGuild. (a) Classified trophic modes and (b) Relative 691 abundance of each trophic mode.

692 Table legend

693 Table 1 Results of indicator species analysis. 